\title{
A Formal and Enantioselective Synthesis of (-)-Serricornin, the Sex Pheromone of the Cigarette Beetle (Lasioderma serricorne F.)
}

\author{
J. Tércio B. Ferreira* and Jacqueline A. Marques \\ Laboratório de Síntese de Produtos Naturais, Departamento de Química \\ Universidade Federal de Săo - Carlos - Sảo Carlos - SP - 13560 - Brasil \\ J. P. Marino* \\ Department of Chemistry, University of Michigan \\ Ann Abor - MI - 48109 - USA
}

\begin{abstract}
A synthesis of (-)-Serricornin is described. The (4S,5S)-4-methyl-5-ethyl $\delta$-valerolactone 8 has been synthesized with a high degree of enantioselectivity starting from $(R)-(+)-(E)-1$-propenyl $p$-tolylsulfoxide 2, having the enantioselective Marino's lactonization as the key step.
\end{abstract}

A number of stereoselective syntheses of serricomin, the sex pheromone of the cigarette beetle (Lasioderma serricorne F.), have been reported in the last few years. ${ }^{1}$ The most active stereoisomer of this class of pheromones has been shown to be the $(4 S, 6 S, 7 S)$-isomer ${ }^{2}$ (1) through a series of structure-activity studies.<smiles>CCC(=O)[C@H](C)C[C@@H](C)[C@@H](CC)OC(C)=O</smiles>

(1)

In this paper we report the synthesis of $(4 S, 5 S)-4$-methyl-5-ethyl 8-valerolactone 8 , with a high degree of enantioselectivity. Lactone 8 has already been transformed into Serricomin by Sato and coworkers. ${ }^{3}$ The critical step in our synthesis for installing the chiral centers involves an enantioselective lactonization reaction of optically active vinyl sulfoxides, discovered by one of us. ${ }^{4}$ The overall synthetic plan is outlined in Scheme 1. 
<smiles>C/C=C/S(=O)[Ga]C</smiles>

(2)

(6)

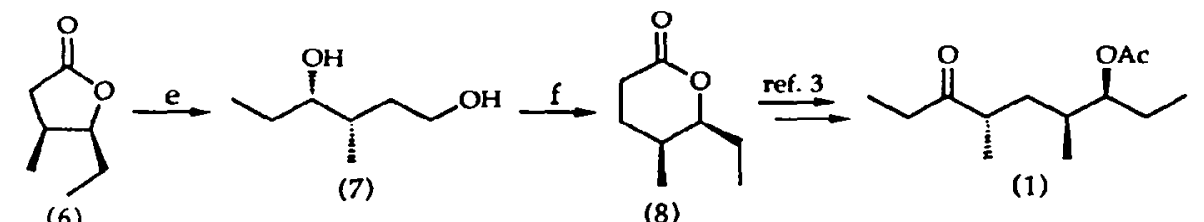<smiles>C/C=C(/CC)S(=O)[Ge]C</smiles>

(3)<smiles>CC[C@]1([Se]C)OC(=O)C(Cl)(Cl)[C@@H]1C</smiles>

(4)<smiles>CC[C@]1([SeH])OC(=O)C[C@H]1C</smiles>

(5)

reagents: (a) i. I.DA, THF, HMPA, $-78^{\circ} \mathrm{C}$, ii. EtI, $-78{ }^{\circ} \mathrm{C}, 63 \%$; (b) $\mathrm{Cl}_{3} \mathrm{CCOCl}, \mathrm{Zn}(\mathrm{Cu})$, THF, $-40{ }^{\circ} \mathrm{C}, 96 \%$; (c) Al(Hg), THF, MeOH, H2O, r.t., 84\%; (d) RaNi, EtOH, $0{ }^{\circ} \mathrm{C}, 66 \%$; (e) LAH, Et $t_{2} \mathrm{O}, 0^{\circ} \mathrm{C}$-r.t., 98\%; (f) i. p-TsCl, Py, $\mathrm{CHCl}_{3}, 0^{\circ} \mathrm{C}$, ii. $\mathrm{NaCN}$, DMSO, NaI, $90-95^{\circ} \mathrm{C}, 67 \%$, iii. $\mathrm{KOH}, \mathrm{EtOH}, \mathrm{H}_{2} \mathrm{O}$, reflux, $\mathrm{H}_{3} \mathrm{O}^{+}$then benzene, $p$-TsOH, $89 \%$.

\section{Scheme 1}

Our synthesis begins with the readily available (E)-1-propenyl-(R)-ptolylsulfoxide 2 prepared by a Horner-Emmons reaction of optically pure $(R)$-(t)-dimethylphosphorylmethyl p-tolylsulfoxide. 5 Deprotonation of vinyl sulfoxide 2 to generate the vinyl anion is effected with LDA, and subsequent quenching with ethyl iodide produces the requisite $E$-disubstituted vinyl sulfoxide 3 in good yield. 6 The key lactonization process is carried out on the sulfoxide 3 with a large excess of dichloroketene which is generated in situ from trichloroacetyl chloride and zinc-copper couple. This reaction produces a single diastereomer and enantiomer of the dialkyl butyrolactone 4 in $95 \%$ yield. Subsequent removal of the chlorine atoms with aluminum amalgam ${ }^{7}$ in aqueous THF proceeds well and the stage is set for the stereoselective desulfurization of lactone 5 . While desulfurizations in general, and Raney/nickel desulfurizations 8 specifically are not known to proceed with high stereoselectivity, we have found that our butyrolactone systems do in fact, desulfurize with Raney/nickel with retention of configuration. Thus, treatment of lactone 5 with W-2 Raney/nickel ${ }^{9}$ in ethanol led to the desired cis-dialkyl butyrolactone 6 in $66 \%$ yield. Previous studies ${ }^{4}$ in our laboratory on desulfurizations of substituted butyrolactones have consistently given products with retention of configuration at the carbon bearing the sulfur atom.

Simple reduction of the lactone 6 with lithium aluminum hydride yields the optically pure diol 7 with two of the chiral centers of Serricornin in place. Conversion of the diol 7 into the valerolactone 8 required homologation of the diol through selective tosylation 10 of the primary alcohol and subsequent displacement of the 
tosylate with sodium cyanide. 11 This was followed by hydrolysis and lactonization to the relay compound 8 , which was identical spectroscopically to the compound reported by Sato. ${ }^{3}$

The high enantioselectivity of the lactonization process for the preparation of optically pure butyrolactone provides an efficient and predictable method for the construction of chiral centers in acyclic natural products.

Experimental

All operations were carried out under an nitrogen atmosphere with oven-dried glassware. IR spectra were recorded on a Perkin-Elmer 1600 series FT-IR Spectrophotomer. ${ }^{1} \mathrm{H}-\mathrm{NMR}$ spectra and ${ }^{13} \mathrm{C}$-NMR spectrum were obtained on a Brüker WM-360 FT NMR or at Brüker AM-300 FT NMR using $\mathrm{CDCl}_{3}$ as solvent and tetramethylsilane as an internal standard. Optical rotations were measured on a Perkin-Elmer model 241 polarimeter. High resolution mass spectra (HRMS) were determined on a VG 70-250S instrument. Column chromatography was performed using Merck Silica Gel 60 (230-400 mesh).

\section{(R)-(E)-1-propenyl p-tolylsulfoxide (2)}

To a solution of $(R)-(+)$-dimethylphosphorylmethyl p-tolylsulfoxide 5 ( $25.0 \mathrm{~g}$; $95.34 \mathrm{mmol})$ in anhydrous THF $(300 \mathrm{~mL})$ was added a solution of freshly prepared KHMDS (143.01 $\mathrm{mmol})$ in anhydrous THF $(250 \mathrm{~mL})$ at $-78^{\circ} \mathrm{C}$ under a nitrogen atmosphere. After $2.5 \mathrm{~h}$, an excess of freshly distilled acetaldehyde (12.6 g; $286.02 \mathrm{mmols}$ ) was added dropwise at $-78^{\circ} \mathrm{C}$ and stirring was continued at this temperature for $1.5 \mathrm{~h}$. The mixture was then warmed slowly to room temperature, stirred for $2 \mathrm{~h}$, and then quenched by addition of water. The reaction mixture was stirred for 10 minutes and transferred to a separatory funnel. After the layers were separated, the aqueous layer was extracted with liethyl ether $(2 \times 100 \mathrm{~mL})$. The combined organic phases were washed with a saturated sodium chloride solution, water and dried over anhydrous magnesium sulphate. Evaporation of the solvent under reduced pressure gave a crude product which consisted of a 3/1 mixture of the isomeric vinyl sulfoxides $E / Z$, respectively. The crude product was chromatographed

on silica gel (petroleum ether: ethyl acetate, 6:4) to afford $12.5 \mathrm{~g}$ of the desired E-vinyl sulfoxide 2 as an pale yellow oil: yield $(73 \%) ;[\alpha]_{0}=+143\left(c=2.0 ; \mathrm{CHCl}_{3}\right)$.

IR (neat): $v$ 1038, 1442, 1490, 1634, 2937, $3030 \mathrm{~cm}^{-1}$.

${ }^{1} \mathrm{H}-\mathrm{NMR}\left(\mathrm{CDCl}_{3}\right): \delta=1.87$ (d, 3H, J=6.4 Hz); 2.37 (s, 3H); 6.19 (dq, $1 \mathrm{H}, \mathrm{J}=15 ; 1.6 \mathrm{~Hz}$ );

$6.40(\mathrm{dq}, 1 \mathrm{H}, \mathrm{J}=15 \mathrm{~Hz} ; 6.8 \mathrm{~Hz}) ; 7.27(\mathrm{~d}, 2 \mathrm{H}, \mathrm{J}=9.2 \mathrm{~Hz}) ; 7.53(\mathrm{~d}, 2 \mathrm{H}, \mathrm{J}=9.2 \mathrm{~Hz})$.

${ }_{13} \mathrm{C}-\mathrm{NMR}\left(\mathrm{CDCl}_{3}\right): \delta=17.45 ; 21.04 ; 124.17 ; 129.65 ; 135.87 ; 136.02 ; 140.56 ; 141.00$.

MS $(70 \mathrm{eV}): \mathrm{m} / \mathrm{e}=181(\mathrm{M}+1), 180\left(\mathrm{M}^{+}\right), 132(100 \%), 123,117,91,65$.

HRMS: $\mathrm{m} / \mathrm{e}=$ calc. for $\mathrm{C}_{10} \mathrm{H}_{12} \mathrm{SO}: 180.0609$; found: 180.0622 . 


\section{(R)-(E)-1-ethyl-1-(p-tolylsulfinyl)-1-propene (3)}

$\mathrm{n}$-Butyl lithium (66.65 mmols; $25.5 \mathrm{~mL}$ of $2.61 \mathrm{M}$ solution in hexanes) was added under a nitrogen atmosphere to a cold ( $\left.0^{\circ} \mathrm{C}\right)$ solution of dry disopropylamine $(7.30 \mathrm{~g} ; 72.20 \mathrm{mmols})$ in anhydrous THF $(300 \mathrm{~mL})$. After 30 minutes, the solution of LDA was cooled to $-78^{\circ} \mathrm{C}$ and a cold $\left(-78^{\circ} \mathrm{C}\right)$ solution of $(R)$-(E)-1-propenyl p-tolylsulfoxide $2(10 \mathrm{~g} ; 55.54 \mathrm{mmols})$ in anhydrous THF $(50 \mathrm{~mL})$ was added dropwise via a transfer needle under nitrogen. After 30 minutes at $-78^{\circ} \mathrm{C}$, HMPA $(9.95 \mathrm{~g}$; $55.54 \mathrm{mmols} ; 9.66 \mathrm{~mL}$ ) was added, the reaction was stirred for 10 minutes at $-780^{\circ} \mathrm{C}$ and then ethyl iudide ( $14.73 \mathrm{~g} ; 94.42 \mathrm{mmols} ; 7.55 \mathrm{~mL}$ ) was added. The reaction mixture was then stirred for an additional hour at $-780^{\circ} \mathrm{C}$, and was then quenched with a saturated ammonium chloride solution at that temperature. The organic layer was separated and the aqueous layer was extracted with ether $(2 \times 50 \mathrm{~mL})$. The combined organic extracts were washed with a saturated sodium chloride solution and dried over anhydrous magnesium sulphate. Evaporation of the solvent under reduced pressure gave a crude product which was chromatographed on silica gel (petroleum ether/ethyl acetate, $7: 3$ ) to give $7.28 \mathrm{~g}$ of the desired sulfoxide 3 as an pale yellow oil: yield $(63 \%) ;[\alpha]_{D}=+43.3\left(\mathrm{c}=2.0 ; \mathrm{CHCl}_{3}\right)$.

IR (neat): $v 1053,1451,1645,2970,3053 \mathrm{~cm}^{-1}$.

${ }^{1} \mathrm{H}-\mathrm{NMR}\left(\mathrm{CDCl}_{3}\right): \delta=0.82(\mathrm{t}, 3 \mathrm{H}, \mathrm{J}=7.3 \mathrm{~Hz}) ; 1.85$ (d, $\left.3 \mathrm{H}, \mathrm{J}=6.5 \mathrm{~Hz}\right): 2.15(\mathrm{q}, 2 \mathrm{H}, 9.2 \mathrm{~Hz}$ ): $2.43(\mathrm{~s}, 3 \mathrm{H}) ; 6.50$ (q, $1 \mathrm{H}, \mathrm{J}=4.6 \mathrm{~Hz}) ; 7.29(\mathrm{~d}, 2 \mathrm{H}, \mathrm{J}=10.5 \mathrm{~Hz}) ; 7.48$ (d, 2H, J=10.5 Hz).

${ }^{13} \mathrm{C}-\mathrm{NMR}\left(\mathrm{CDCl}_{3}\right): \delta=13.86 ; 13.92 ; 17.62 ; 21.66 ; 125.37 ; 129.86 ; 130.25 ; 140.17 ; 141.34$; 147.12 .

MS $(70 \mathrm{eV}): \mathrm{m} / \mathrm{e}=209(\mathrm{M}+1), 208\left(\mathrm{M}^{+}\right), 151,140,92,65,41(100 \%)$.

HRMS: $\mathrm{m} / \mathrm{e}=$ calc. for $\mathrm{C}_{12} \mathrm{H}_{16} \mathrm{SO}: 208.0922$; found: 208.0917 .

\section{(3R,4R)-2,2-dichloro-4-ethyl-3-methyl-4-p-tolylthio y-butyrolactone (4)}

A solution of trichloroacetyl chloride $(56.82 \mathrm{~g} ; 312.5$ mmols; $34.6 \mathrm{~mL}$ ) in anhydrous THF (100 mL) was added during $30 \mathrm{~min}$ to a suspension of the vinyl sulfoxide 3 ( $13 \mathrm{~g} ; 62.5 \mathrm{mmols}$ ) and zinc-copper couple ${ }^{12}$ (1250 mmols; $81.7 \mathrm{~g}$ ) in anhydrous THF $(250 \mathrm{~mL})$ at $-40^{\circ} \mathrm{C}$. The reaction mixture was then stirred vigorously at $-40^{\circ} \mathrm{C}$ for an additional hour and then filtered through a pad of Celite into an ice-cold saturated sodium bicarbonate solution. The zinc residue was washed with anhydrous ethyl ether $(3 \times 50 \mathrm{~mL})$ and the combined filtrate and washings were placed in a separatory funnel. The aqueous layer was extracted with ether $(3 \times 50 \mathrm{~mL})$, and the combined organic extracts were washed with a saturated sodium chloride solution, and dried over anhydrous magnesium sulphate. The solvent was removed under reduced pressure and the crude product was chromatographed on silica gel 
(petroleum ether/ethyl acetate, 9:1) to afford $19.0 \mathrm{~g}$ of the dichloro lactone 4 as a colorless solid: yield (96\%); m.p. $108-110^{\circ} \mathrm{C}[\alpha]_{b}=+2.96\left(\mathrm{c}=3.0 ; \mathrm{CHCl}_{3}\right)$..

IR $\left(\mathrm{CHCl}_{3}\right):$ v 745, 1166, 1250, 1582, 1802, $2950,3061 \mathrm{~cm}^{-1}$.

${ }^{1} \mathrm{H}-\mathrm{NMR}\left(\mathrm{CDCl}_{3}\right): \delta=1.12(\mathrm{t}, 3 \mathrm{H}, \mathrm{J}=7.5 \mathrm{~Hz}$ ); 1.24 (d, $3 \mathrm{H}, \mathrm{J}=7.2 \mathrm{~Hz}$ ); 1.72 (dq, $2 \mathrm{H}, \mathrm{J}=7.5$ $\mathrm{Hz}$ ); 2.21 (s, $3 \mathrm{H}$ ); 2.74 (q, $1 \mathrm{H}, \mathrm{J}=7.5 \mathrm{~Hz}$ ); 7.07 (d, $2 \mathrm{H}, \mathrm{J}=9.5 \mathrm{~Hz}$ ); 7.25 (d, $2 \mathrm{H}, \mathrm{J}=9.5 \mathrm{~Hz}$ ).

${ }^{13} \mathrm{C}-\mathrm{NMR}\left(\mathrm{CDCl}_{3}\right): \delta$ = 8.45; 8.87; 21.45; 28.08; 52.82; 81.64; 99.77; 124.64; 130.67; 136.96; $141.03 ; 166.90$.

MS (70 eV): $\mathrm{m} / \mathrm{e}=320(\mathrm{M}+2), 319(\mathrm{M}+1), 318(\mathrm{M}+), 239,195,124(100 \%), 91,57$

HRMS: $\mathrm{m} / \mathrm{e}=$ calc. for $\mathrm{C}_{14} \mathrm{H}_{16} \mathrm{SO}_{2} \mathrm{Cl}_{2}$ : 318.0248; found: 318.0249 .

\section{(3S,AR)-4-ethyl-3-methyl-4-p-tolylthio $\gamma$-butyrolactone (5)}

A solution of the dichlorolactone $4(18.50 \mathrm{~g} ; 58.17 \mathrm{mmols})$ in THF (50 mL) was added to a stirred suspension of aluminum amalgam (prepared from $23.5 \mathrm{~g}$ of aluminum pellets according to the procedure given in ref. 7 ) in THF (100 mL), followed by a 1:1 mixture of methanol/distilled water (100 $\mathrm{mL})$. The suspension was stirred at room temperature for $24 \mathrm{~h}$, and then filtered through a pad of Celite 0 . The amalgam was washed with anhydrous ethyl ether $(2 \times 50 \mathrm{~mL})$ and the combined filtrate and washings were dried over anhydrous magnesium sulphate. The solvent was removed under reduced pressure, and the crude product was chromatographed on silica gel (petroleum ether/ethyl acetate, 9:1) to afford $12.22 \mathrm{~g}$ of the desired dechlorinated lactone 5 as a colorless oil: yield $(84 \%) ;[\alpha]_{D}=+66.5\left(\mathrm{c}=2.3 ; \mathrm{CHCl}_{3}\right)$.

IR (neat): $v$ 752, 1454, 1578, 1782, 2959, $3062 \mathrm{~cm}^{-1}$.

${ }^{1} \mathrm{H}-\mathrm{NMR}\left(\mathrm{CDCl}_{3}\right): \delta=1.07-1.15(\mathrm{~m}, 6 \mathrm{H}) ; 1.73-1.81(\mathrm{~m}, 2 \mathrm{H}) ; 2.22$ (dd, 1H, J=17.6; 5.8 $\mathrm{Hz}$ ); 2.33 (s, 3H); 2.49-2.55 (m, $1 \mathrm{H}) ; 2.75$ (dd, $1 \mathrm{H}, \mathrm{J}=17.6 ; 8.8 \mathrm{~Hz}) ; 7.12$ (d, $2 \mathrm{H}, \mathrm{J}=9.5 \mathrm{~Hz}$ ); $7.42(\mathrm{~d}, 2 \mathrm{H}, \mathrm{J}=9.5 \mathrm{~Hz})$.

${ }^{13} \mathrm{C}-\mathrm{NMR}\left(\mathrm{CDCl}_{3}\right): \delta=8.96 ; 14.56 ; 21.28 ; 27.10 ; 37.72 ; 37.87 ; 100.65 ; 126.06 ; 129.87 ;$ $136.41 ; 139.60 ; 175.19$.

MS $(70 \mathrm{eV}): \mathrm{m} / \mathrm{e}=251(\mathrm{M}+1), 250\left(\mathrm{M}^{+}\right), 161,127(100 \%), 109,91,84,57$.

HRMS: $\mathrm{m} / \mathrm{e}=$ calc. for $\mathrm{C}_{14} \mathrm{H}_{18} \mathrm{SO}_{2}$ : 250.1028; found: 250.1018 .

(3S,4S)-4-ethyl-3-methyl $\gamma$-butyrolactone (6)

A solution of lactone 5 (11.8 g; $47.2 \mathrm{mmols})$ in absolute ethanol (50 mL) was added to a stirred suspension of freshly prepared Raney nickel (ca. $35 \mathrm{~g}$ activated W-2 according to procedure given in ref. 9) in absolute ethanol $(100 \mathrm{~mL})$ at $0^{\circ} \mathrm{C}$. The reaction mixture was stirred at $0{ }^{\circ} \mathrm{C}$ for 30 minutes and then at room temperature until TLC indicated complete consumption of the starting material (ca. $12 \mathrm{~h}$ ). The ethanolic solution was then decanted and the Raney nickel was washed with ether $(2 \times 30 \mathrm{~mL})$. The combined organic extracts were filtered through a glass fritted funnel. The 
solvents were removed under reduced pressure and the crude product was chromatographed on silica gel (petroleum ether/ethyl acetate, 9:1) to give $3.98 \mathrm{~g}$ of the desired product 6 as an colorless oil: yield $(66 \%) ;[\alpha]_{D}=-34.4\left(\mathrm{c}=2.0 ; \mathrm{CHCl}_{3}\right)$.

IR (neat): $v 811,930,1128,1223,1466,1777 \mathrm{~cm}^{-1}$.

' $\mathrm{H}-\mathrm{NMR}\left(\mathrm{CDCl}_{3}\right): \delta=0.92(\mathrm{t}, 3 \mathrm{H}, \mathrm{J}=7.5 \mathrm{~Hz}) ; 1.12(\mathrm{~d}, 3 \mathrm{H}, \mathrm{J}=7.5 \mathrm{~Hz}) ; 1.85-2.00(\mathrm{~m}, 2 \mathrm{H})$; 2.2. (dd, 1H, J=16.8; $3.0 \mathrm{~Hz}) ; 2.40-2.60(\mathrm{~m}, 1 \mathrm{H}) ; 2.70(\mathrm{dd}, 1 \mathrm{H}, \mathrm{J}=16.8 ; 7.6 \mathrm{~Hz}) ; 3.55-3.64$ $(\mathrm{m}, 1 \mathrm{II})$.

${ }^{13} \mathrm{C}-\mathrm{NMR}\left(\mathrm{CDCl}_{3}\right): \delta=13.53 ; 14.31 ; 26.57 ; 34.47 ; 37.53 ; 111.74 ; 176.28$.

MS (70 eV): $m / e=128\left(M^{+}\right), 99,71,59.42(100 \%)$.

\section{(3R,4R)-3-methyl-1,4-hexanediol (7)}

To a suspension of lithium aluminum hydride (1.26 g; $33.32 \mathrm{mmols})$ in anhydrous ethyl ether $(100 \mathrm{~mL})$ cooled $\left(0^{\circ} \mathrm{C}\right)$ under nitrogen was added dropwise a solution of the lactone $6(3.80 \mathrm{~g} ; 29.65 \mathrm{mmols})$ in anhydrous ethyl ether $(20 \mathrm{~mL})$. The reaction mixture was stirred for 30 minutes at $0^{\circ} \mathrm{C}$ and then for $3 \mathrm{~h}$ at room temperature. The reaction mixture was cooled $\left(0^{\circ} \mathrm{C}\right)$ and quenched with water $(1.3 \mathrm{~mL}), 10 \%$ sodium hydroxide solution $(1.3 \mathrm{~mL})$ and water $(5.2 \mathrm{~mL})$ and was then stirred for an additional 30 minutes. The reaction mixture was filtered through a glass fritted funnel, the salts were washed with ethyl ether $(2 \times 50 \mathrm{~mL})$ and the combined filtrate and washings were dried over anhydrous magnesium sulphate. The solvent was removed under reduced pressure to afford $3.84 \mathrm{~g}$ of the diol 7 as a viscous colorless oil which was used in the next step without further purification: yield (98\%); $[\alpha]_{D}=+12.5\left(\mathrm{c}=1.0 ; \mathrm{CHCl}_{3}\right)$. IR (neat): $v 1010,1132,1237,2943,3406(\mathrm{br}) \mathrm{cm}^{-1}$. ${ }^{1} \mathrm{H}-\mathrm{NMR}\left(\mathrm{CDCl}_{3}\right): \delta=0.82(\mathrm{t}, 3 \mathrm{H}, \mathrm{J}=7.2 \mathrm{~Hz}) ; 0.95(\mathrm{~d}, 3 \mathrm{H}, \mathrm{J}=7.2 \mathrm{~Hz}) ; 1.15-1.25(\mathrm{~m}, 5 \mathrm{H})$; $3.40(\mathrm{~s}, 1 \mathrm{H}, \mathrm{OH}), 4.05-4.30(\mathrm{~m}, 3 \mathrm{H})$.

${ }^{13} \mathrm{C}-\mathrm{NMR}\left(\mathrm{CDCl}_{3}\right): \delta=10.13 ; 14.93 ; 24.34 ; 31.79 ; 32.55 ; 77.30 ; 77.65$.

(4S,5S)-5-ethyl-4-methyl \&-valerolactone (8)

Pyridine (4.55 g; $57.48 \mathrm{mmols} ; 4.6 \mathrm{~mL})$ was added to a cold $\left(0^{\circ} \mathrm{C}\right)$ solution of the diol 7 ( $3.8 \mathrm{~g} ; 28.74 \mathrm{mmols})$ in chloroform $(30 \mathrm{~mL})$ followed by the addition of p-toluenesulfonyl chloride $(5.48 \mathrm{~g} ; 28.74 \mathrm{mmols})$ in small portions. The reaction mixture was stirred at $0{ }^{\circ} \mathrm{C}$, and was monitored by TLC until the starting material was consumed (ca. $14 \mathrm{~h}$ ). After filtration through a pad of Celite the solvent was evaporated under reduced pressure and the excess pyridine was removed in vacuo $(0.5 \mathrm{mmHg})$. To a solution of the crude tosylate in DMSO $(30 \mathrm{~mL})$ was added sodium cyanide ( $1.28 \mathrm{~g} ; 26.19 \mathrm{mmols}$ ) and sodium iodide $(0.52 \mathrm{~g} ; 3.5 \mathrm{mmols}$ ). The reaction mixture was heated at $90-95^{\circ} \mathrm{C}$ for $48 \mathrm{~h}$, cooled to room temperature, and poured into 
water. The reaction mixture was extracted with ethyl ether $(2 \times 50 \mathrm{~mL})$; the combined extracts were dried over anhydrous magnesium sulphate and the solvent was evaporated under reduced pressure. The crude product was chromatographed on silica gel (petroleum ether/ethyl acetate, 9:1) to afford $1.63 \mathrm{~g}(67 \%)$ of the hydroxynitrile as an oil: ${ }^{1} \mathrm{H}-\mathrm{NMR}\left(\mathrm{CDCl}_{3}\right): \delta=0.71-1.00(\mathrm{~m}, 6 \mathrm{H}) ; 1.17-1.32(\mathrm{~m}, 5 \mathrm{H})$; $2.41(\mathrm{t}, 2 \mathrm{H}, \mathrm{J}=6.8 \mathrm{~Hz})$; $3.36(\mathrm{~s}, 1 \mathrm{H}, \mathrm{OH}), 4.0-4.25(\mathrm{~m}, 2 \mathrm{H})$.

A mixture of the hydroxynitrile ( $1.15 \mathrm{~g} ; 8.16 \mathrm{mmols})$, water $(3 \mathrm{~mL})$ and sodium hydroxide ( $6.20 \mathrm{~g} ; 155.04 \mathrm{mmols}$ ) was then refluxed for $48 \mathrm{~h}$ and then cooled to room temperature and diluted with water. The reaction mixture was neutralized with concentrated $\mathrm{HCl}$, extracted with dichloromethane $(3 \times 30 \mathrm{~mL})$, dried over anhydrous magnesium sulphate and then concentrated under reduced pressure. To the residue was added benzene $(25 \mathrm{~mL})$ and a catalytic amount of p-toluenesulfonic acid (ca. $0.15 \mathrm{~g}$ ). The reaction mixture was then refluxed for $24 \mathrm{~h}$ using an Dean-Stark apparatus, cooled to room temperature and diluted with ethyl ether. The aqueous layer was extracted with ethyl ether $(2 \times 20 \mathrm{~mL})$ and the combined organic extracts were washed with a sodium bicarbonate solution, a sodium chloride solution, water and finally dried over anhydrous magnesium sulphate. The solvent was removed under reduced pressure and the product was chromatographed on silica gel (hexane/ethyl acetate, 9: 1) to give $1.03 \mathrm{~g}$ of the lactone 8 as an colorless oil: yield $(89 \%) ;[\alpha]_{D}=-63.90\left(c=1.0 ; \mathrm{CHCl}_{3}\right)\left[\right.$ lit. $\left.[\alpha]_{D}=-65.82\left(c=1.0 ; \mathrm{CHCl}_{3}\right)\right]$.1d

IR (neat): $\vee 1721 \mathrm{~cm}^{-1}$.

${ }^{1} \mathrm{H}-\mathrm{NMR}\left(\mathrm{CDCl}_{3}\right): \delta=0.92(\mathrm{~d}, 3 \mathrm{H}, \mathrm{J}=7.6 \mathrm{~Hz})$ ); $1.20(\mathrm{t}, 3 \mathrm{H}, \mathrm{J}=7.6 \mathrm{~Hz}) ; 1.67-1.91(\mathrm{~m}$, $5 \mathrm{H}) ; 2.36(\mathrm{~m}, 2 \mathrm{H}) ; 4.18$ (ddd, $1 \mathrm{H}, \mathrm{J}=6.2 ; 7.8 \mathrm{~Hz}$ ).

${ }^{13} \mathrm{C}-\mathrm{NMR}\left(\mathrm{CDCl}_{3}\right): \delta=10.60 ; 12.35 ; 23.86 ; 25.67 ; 26.58 ; 28.66 ; 84.90 ; 171.32$.

MS $(70 \mathrm{eV}): \mathrm{m} / \mathrm{e}=143\left[(\mathrm{M}+\mathrm{H})^{+}\right], 113,84,56(100 \%)$

HRMS: $m / e=$ calc. for $\mathrm{C}_{8} \mathrm{H}_{14} \mathrm{O}_{2} \mathrm{H}: 143.1072$; found: 143.1075 .

\section{Acknowledgements}

We acknowledge partial support of this work by the NIH, for grant CA 22237 to J.P.M. We also wish to thank International Foundation for Science and the following Brazilian agencies: CAPES, FAPESP and CNPq for a fellowship to J.A.M.

\section{References}

1. (a) Mori, M.; Chuman, T.; Kohno, M.; Kato, K.; Noguchi, M.; Nomi, H.; Mori, K. Tetrahedron Lett., 1982, 23, 667; (b) Mori, K.; Watanabe, H. Tetrahedron, 1985, 41, 3423; (c) Hoffmann, R.W.; Helbig, W.; Ladner, W. Tetrahedron Lett., 1982, 23, 3479; (d) Takano, S.; Sekiguchi, Y.; Ogasawara, K. Heterocycles, 1989, 29, 445; 
(e) Moyashita, M.; Toshimitsu, Y.; Shiratani, T.; Irie, H. Tetrahedron Asymmetry $1993,4,1573$.

2. (a) Chuman, T.; Kohno, M.; Kato, K.; Noguchi, M.; Nomi, H.; Mori, K. Agric. Biol. Chem., 1981, 45(9), 2019; (b) Chuman, T.; Kato, K.; Noguchi, M. Agric. Biol. Chem., 1979, 43(9). 2005; (c) Mori, K.; Nomi, H.; Chuman, T.; Kohno, M.; Kato, K.; Noguchi, M. Tetrahedron, 1982, 3705; (d) Okada, K.; Watanabe, A.; Mori, M.; Shimazaki, K.; Chuman, T.; Mochizuki, F.; Shibyya, T. J. Insect Physiol., 1992, 38(9). 705; (e) Levinson, A.R.; Levinson, H.Z. J. Appl. Entomol., 1986, 101 (3), 282.

3. Sato, F.; Kobayashi, Y.; Kitano, Y.; Takeda, Y.Tetrahedron, 1986, 42, 2937.

4. for recent summary of the lactonization see: (a) Marino, J.P. Pure \& Applied Chem., 1993,65(4), 667; (b) Marino, J.P.; Bogdan, S.; Kimura, K. J. Am. Chem. Soc.., 1992, 114, 5566; (c) Marino, J.P.; Fernandez de la Pradilla, R.Tetrahedron Lett., 1985, 26, 5381; (d) Marino, J.P.; Fernandez de la Pradilla, R.; Laborde, E. Synthesis, 1987, 1088.

5. (a) Mikolajczyk, M.; Grzejszczak, S.; Zatorski, A. J. Org. Chem., 1975, 40, 1979;

(b) Mikolajczyk, M.; Midura, W.; Grzejszczak, S.; Zatorski, A.; Chefczyuska, A. J. Org. Chem., 1978, 43, 473.

6. (a)Posner, G. H.; Tang, P. W.; Mallano, J. P. Tetrahedron Lett. 1978, 42, 3995; (b) Schmidt, R. R.; Speer, H.; Schmid, B. Tetrahedron Lett. 1979, 44, 4277.

7. Fieser, L.F.; Fieser, M.; Reagents for Organic Synthesis, Vol. 1. John Wiley and Sons, New York, N. Y., 1967, p. 20.

8. Bonner, W. A.; Grimm, R. A. in Kharasch, N.; Meyers, C. Y. Eds. The Chemistry of Organic Sulfur Compounds, Vol. 2, Pergamon Press, Oxford, 1966, p. 35.

9. Mozingo, R. Org. Syntheses Coll. Vol. 3, 181, 1955.

10. Kabalka, G.W.; Varma, M.; Varma, R.S. J. Org. Chem., 1986, 51, 2386.

11. (a)Harada, T.; Kurokawa, H.; Kagamihara, Y.; Tanaka, S.; Inoue, A.; Oku, A. J. Org. Chem. 1992, 57, 1413 ; (b) Purdum, W. R.; Berlin, K. D. Org. Prep. Proc. Int. 1975, 7, 283.

12. Rawson, R.J.; Harrison, I.T. J. Org. Chem., 1970, 35, 2057. 